УДК 37.01(092)(438)

DOI 10.31654/2663-4902-2020-PP-2-133-141

Lisovets 0.

doktor habilitowany, profesor Katedry Pedagogiki Społecznej i Pracy Socjalnej, Niżyński Państwowy Uniwersytet im. M. Gogola, Ukraina

\title{
Macioch M.
}

studentka studiów mgr Pedagogika opiekuńczo-wychowawcza profilaktyką społeczną Państwowa Wyższa Szkoła Zawodowa w Chełmie, Polska

\section{WKŁAD ALEKSANDRA KAMIŃSKIEGO W ROZWÓJ TEORII WYCHOWANIA}

Tekst pokazuje wkład wybitnego pedagoga, instruktora harcerski A. Kamińskiego w rozwój teorii wychowania. Ruch zuchowy do dziś korzysta z podstawowych struktur, założeń metodycznych i rozwiązań organizacyjnych stworzonych przez Kamińskiego. Dorobek pedagogiczny $A$. Kamińskiego zawiera dzieła podejmujące problematyke metod wychowania opartych na oddziaływaniach aktywizujących, grupowych oraz organizowaniu działalności samorządnej. A. Kamiński analizował funkcjonowanie zespołów amatorskich, ich rolę $w$ procesie samokształcenia $i$ uspołeczniania młodzieży $i$ osób dorosłych, w tym także seniorów, oraz motywy, dla których ludzie działają w zespołach amatorskich.

Słowa kluczowe: wychowanie, teoria wychowania, metoda grupowa, samorząd dzieci $i$ młodzieży, ruch zuchowy.

Sformułowanie problemu. Rola pedagoga wyraża się w szerokim spektrum obowiązków i powinności. Jednym z nich jest bycie dla wychowanków autorytetem wzorem cnót, wiedzy, doświadczenia, kompetencji, jak również postawy życiowej. Aby jednak wychowawca mógł być autorytetem dla swoich uczniów-wychowanków, nie tylko z tytułu władzy, ale z podziwu i chęci naśladowania, sam winien zwracać się w stronę ludzi światłych. Wychowawca, który nie wykształcił swojego pedagogicznego warsztatu, doceniając mądrość klasyków dziedziny, może napotkać trudności w budowaniu swojego autorytetu u podopiecznych.

Wybór Aleksandra Kamińskiego jako pedagoga wartego przywołania związany jest z prezentowanym przez niego holistycznym podejściem do działań wychowawczych. Spostrzeżenia i propozycje jakie formułował, obejmują ludzi w różnym wieku, poczynając od dzieci, kończąc na seniorach. Dostrzegał on także, że sfery funkcjonowania człowieka istnieją integralnie, co akcentował w proponowanych metodach oddziaływań.

Analiza najnowszych badań i publikacji. O A. Kamińskim - wybitnym pedagogu i wyjątkowym człowieku - napisano wiele prac indywidualnych i zbiorowych oraz wspomnień. Przeglądem życia, działalności wychowawczej i twórczości pedagogicznej A. Kamińskiego została przedstawiona w pracach takich uczonych jak A. Janowski, K. Heska-Kwaśniewicz, W. Okoń, K. Olbrycht, D. Polańczyk, J. Półturzycki, B. Wachowicz, A. Zawadzka i in. Nie wszystkie jego działania i prace są równie znane, a tym samym nie wszystkie są tak cenione i wykorzystywane przez współczesnych pedagogów, jak na to zasługują. Jednym z takich mniej znanych obszarów jest wkład A. Kamińskiego w rozwój teorii wychowania.

Przedstawianie materiału głównego. Krótko przedstaw biografię A. Kamińskiego, który jest $w$ polskiej pedagogice znany przede wszystkim jako wybitny pedagog społeczny, przedstawiciel środowiska łódzkiego, z którego wyrosła polska pedagogika społeczna. A. Kamiński urodził się 1903 roku. We wczesnym dzieciństwie zamieszkał wraz z rodziną w Kijowie, tam też uczęszczał do rosyjskiej szkoły powszechnej. Studiował historię i archeologię na Uniwersytecie Warszawskim [8]. Po ukończeniu studiów rozpoczął pracę jako nauczyciel historii, a jednocześnie zadebiutował jako pisarz na łamach "Płomyka". Od 1918 r. A. Kamiński nieprzerwanie związany był ze Związkiem Harcerstwa Polskiego. W 1922 mianowany został przodownikiem, w 1924 - 
podharcmistrzem, a 1927 r. harcmistrzem. Uważany jest za współtwórcę i teoretyka ruchu zuchowego w Polsce, spod jego pióra wyszły podręczniki metodyczne dla instruktorów zuchowych takie jak: "Antek Cwaniak" (1932), "Książka wodza zuchów" (1933) i "Krąg rady" (1935). W latach 1956 - 58 przewodniczący Prezydium Naczelnej Rady Harcerskiej [9, s. 149].

W czasie wojny był działaczem Polski Podziemnej, współorganizatorem Szarych Szeregów, redaktorem "Biuletynu Informacyjnego" oraz komendantem organizacji małego sabotażu "Wawer". Po II wojnie światowej mieszkał w Łodzi, gdzie pracował naukowo, w latach 1969-1973 był profesorem Uniwersytetu Łódzkiego. Zmarł w 1978 r. w Warszawie [6, s. 215].

Dorobek pedagogiczny A. Kamińskiego zawiera dzieła podejmujące problematykę metod wychowania opartych na oddziaływaniach aktywizujących, grupowych oraz organizowaniu działalności samorządnej. Ponadto A. Kamiński analizował funkcjonowanie zespołów amatorskich, ich rolę w procesie samokształcenia i uspołeczniania młodzieży i osób dorosłych, w tym także seniorów, oraz motywy, dla których ludzie działają w zespołach amatorskich.

Koncepcja pedagogiczna Aleksandra Kamińskiego. Stworzona przez A. Kamińskiego koncepcja pedagogiczna opiera się na uznanych przez niego wartościach i postawach moralnych. Za najważniejszą z nich uznał Kamiński dzielność, gdyż jego zdaniem jest ona spiritus movens istnienia innych wartości moralnych takich jak altruizm, odpowiedzialność, przyjaźń, braterstwo, opanowanie, sprawiedliwość, wytrwałość w dążeniu do wytyczonych celów, hart ducha czy optymizm. Wśród fundamentalnych dla A. Kamińskiego postaw odnaleźć można permanentne dążenie do doskonalenia się w zakresie własnej osobowości, kształtowania uczuć wyższych, jak i nabywania umiejętności [7, s. 77].

Kamiński stawiał wysokie wymagania osobie wychowawcy twierdząc że "najlepsza metoda - w rękach człowieka obojętnego lub niezdolnego nic nie daje; gorzej - daje wyniki opłakane" [2, s. 4]. Jego zdaniem efektywność procesu dydaktycznowychowawczego zależy głównie od osobowości nauczyciela i prezentowanych przezeń przymiotów, takich jak życzliwość wobec uczniów i jego przywiązania do pracy, pogoda ducha, okazywanie zaufania wychowankom, umiejętność odkrywania ich zdolności oraz wiara $\mathrm{w}$ siły podopiecznych. Jego zdaniem ogromne znaczenie mają postawy, jakie wychowawca prezentuje, tj. osobisty przykład nauczyciela [7, s. 77].

Koncepcja pedagogiczna A. Kamińskiego dotyczy również sposobów organizowania lekcji przy pomocy zabaw dydaktycznych, zajęć w grupach, listy umiejętności i swoistej atmosfery wychowawczej. Kamiński proponował wykorzystywanie zabaw dydaktycznych jako sposobu urozmaicenia zajęć lekcyjnych $w$ celu wzmożenie procesu uczenia się. W związku z tym wskazał pewne obostrzenia co do ich stosowania. Postulował, aby były organizowane $z$ umiarem i tylko $w$ tych fragmentach lekcji, w których spodziewamy się ich użyteczności pod względem dydaktyczno-wychowawczym oraz były stosowane tylko do momentu, do którego "porywa" dzieci i młodzież. $Z$ tego też powodu sugerował, aby zabawy dydaktyczne nie były zbieżne z zabawami, z jakimi uczniowie się spotykają na zbiórkach zuchowych lub harcerskich. Ponadto nie popierał Kamiński, zwłaszcza u dzieci w młodszym wieku szkolnym, stosowania gier, czyli aktywności, które podsycają u uczniów współzawodnictwo. A. Kamiński proponował natomiast, aby uczniowie współtworzyli proces dydaktyczny. Zalecał, aby bodźcem do prowadzenia zabawy dydaktycznej była kreatywność uczniów - aby zabawy prowadzone były zgodnie z ich pomysłami, odzwierciedlając ich zainteresowania, a nie zainteresowania dorosłych, jednakże nie były równoważnikiem nieładu i chaosu, to jest nie prowadziły do zaniechania przestrzegania elementarnych zasad [2, s. 48-51].

Zaproponowane przez A. Kamińskiego zajęcia w grupach polegają na pracy uczniów w zespołach podczas lekcji. Praca w grupach zakłada, iż każda z grup ma do wykonania zadania o charakterze dydaktycznym. Metoda ta ma służyć aktywnemu udziałowi uczniów w lekcji oraz wzajemnemu weryfikowaniu osiągnięć dydaktycznych przez uczniów. Zgodnie ze spostrzeżeniami Kamińskiego w procesie pracy w grupach najlepiej sprawdzają zespoły stałe, nie większe niż sześcioosobowe, podobnie jak jest to praktykowane w zastępach harcerskich. 
W kwestii organizowania zespołów A. Kamiński opowiadał się za tym, aby wychowankowie sami dobierali się w zespoły, wedle własnego uznania. Jego zdaniem intuicja dziecka na ogół w lepszym stopniu pozwoli mu rozeznać, w jakim środowisku rówieśniczym będzie ono czuło się dobrze, aniżeli nauczyciel. Podkreślał on, że samodzielność w tym zakresie zwiększa prawdopodobieństwo odnalezienia się wychowanka w grupie wychowawczej lub klasie oraz jego prawidłowego rozwoju psychicznego w społeczności grupy [2, s. 101]. Niemniej jednak nauczyciel może dokonywać drobnych korekt. A. Kamiński proponował sposoby łączenia uczniów w zespoły w zależności od poziomu znajomości uczniów-wychowanków przez nauczycielawychowawcę lub innych znaczących czynników.

Tabela 1

\section{Sposób tworzenia grup, zalecany przez A. Kamińskiego}

\begin{tabular}{|l|l|}
\hline \multicolumn{1}{|c|}{ Sposób tworzenia grup } & \multicolumn{1}{c|}{ Sytuacja } \\
\hline $\begin{array}{l}\text { Zalecanie przez nauczyciela utworzenia w } \\
\text { klasie określonej liczby zespołów, by "były } \\
\text { mniej więcej równe". }\end{array}$ & $\begin{array}{l}\text { Uczniowie nie znają się jeszcze } \\
\text { dokładnie lub gdy nie zna ich również } \\
\text { dobrze nauczyciel. }\end{array}$ \\
\hline $\begin{array}{l}\text { Uczniowie wybierają najpierw spośród } \\
\text { siebie tzw. grupowych, a następnie } \\
\text { deklarują do nich swą przynależność } \\
\text { według własnych upodobań. }\end{array}$ & $\begin{array}{l}\text { Nauczyciel nie zna uczniów, a } \\
\text { uczniowie natomiast znają się dobrze } \\
\text { nawzajem. }\end{array}$ \\
\hline $\begin{array}{l}\text { Mianowanie przez nauczyciela grupowych } \\
\text { spośród wyróżniających się uczniów i } \\
\text { dobrowolne przyłączanie się do nich } \\
\text { pozostałych uczniów klasy. }\end{array}$ & Nauczyciel zna dobrze klasę. \\
\hline $\begin{array}{l}\text { Nauczyciel pozwala na dobieranie się } \\
\text { uczniów w grupy dowolnie tak, aby } \\
\text { uczniom "było ze sobą dobrze pracować". }\end{array}$ & Zalecane jedynie w klasach starszych. \\
\hline \multicolumn{2}{|c|}{ Źródb: M. kobocki, Teoria wychowania, } \\
\hline
\end{tabular}
210.

Źródło: M. Łobocki, Teoria wychowania, Oficyna Wyd. Impuls, Kraków 2009, s. 209_

A. Kamiński rekomendował także wykorzystywanie metod grupowych również w realizacji zadań o charakterze organizacyjnym i wychowawczym poprzez pełnienie dyżurów, dbałość o higienę i porządek w klasie, udzielanie pomocy uczniom słabszym i wywieranie wpływu na opinię klasy w sprawach moralno-społecznych.

Lista umiejętności w koncepcji pedagogicznej A. Kamińskiego również stanowi obok zabaw dydaktycznych i zajęć w grupach - skuteczny sposób urozmaicania i usprawniania lekcji. Wywodzi się ona z praktyki zdobywania sprawności w zastępach harcerskich, a polega na wpisywaniu uczniów na listę umiejętności jako dowód opanowanej przez ucznia umiejętności, nie zaś wyróżnienia [7, s. 77]. Wpis odbywa się po sprawdzeniu przez nauczyciela stopnia opanowania umiejętności podczas swoistej próby. Nauczyciel może przeprowadzić próbę w obecności klasy lub też na osobności - przed lekcją bądź po niej. Możliwe jest również powołanie tzw. komisji prób, złożonych z 2-3 uczniów, uprawnionych do sprawdzenia umiejętności jak i upoważnienie kilkorga rodziców do przeprowadzania prób w ich domach [2, s. 158-159].

A. Kamiński podkreślał, że nie chodzi tu li tylko o wiedzę. Unikatowość tej formy prowadzenia procesu edukacyjnego polega na przekonaniu, że w życiu - obok wiadomości są potrzebne także rozwijane w wyniku ćwiczeń dyspozycje do wykonywania określonych czynności psychofizycznych i umysłowych. Szczególnie w starszych klasach lista umiejętności obejmuje obok umiejętności szkolnych również praktyczne umiejętności ponadprogramowe, zwane przez A. Kamińskiego "amatorskimi" [7, s. 78].

Funkcje jakie A. Kamiński przypisał zespołom amatorskim to m. in. motywowanie amatorów do samorealizacji, stwarzanie przestrzeni umożliwiającej kształcenie, tworzenie 
wspólnoty, umożliwianie osiągnięcia sukcesu i stwarzanie warunków do konsumpcji i urzeczywistniania kultury. A. Kamiński przypisuje również zespołom amatorskim funkcje "szkoły dzielności" i "szkoły charakteru" [5, s. 324].

Szczególnie A. Kamiński skupiał się nad funkcją samokształcenia dzięki zespołom amatorskim. Przejawy samokształcenia (jak ują to w "Studiach i szkicach pedagogicznych"), jakie można zaobserwować w zakresie działalności zespołów amatorskich to ukształtowanie nawyku chętnego konsumowania dorobku kulturalnego $z$ danej dziedziny, nauka $i$ zachęcanie do czynnego zdobywania wiedzy z określonej dziedziny kultury oraz wdrażanie do biegłego praktykowania umiejętności z zakresu amatorskich zamiłowań [5, s. 321].

Analiza, jaką objął zespoły amatorskie, zaowocowała wskazaniem przyczyn, dla których ludzie angażują się $w$ ich tworzenie. Jedną z nich jest użyteczność dziedziny amatorstwa dla danej osoby, rozumiana jako możliwość zaspokojenia potrzeb niematerialnych, to jest na przykład wykorzystanie swojego potencjału czy aktywne spędzenie wolnego czasu. Motywem zachęcających ludzi do wiązania się z zespołami amatorskimi jest również pragnienie samourzeczywistnienia, związane z zaspokajaniem potrzeb typowo ludzkich, tj. kontaktu z kulturą, także twórczości, samorozwoju, zdobywanie wiedzy. Ważnymi elementami, motywującymi amatorów różnych dziedzin do łączenia się w grupy, jest współżycie koleżeńskie oraz aktywność społeczna. Zdaniem A. Kamińskiego potrzeba kompensacji braków jest również dla wielu osób motywem do włączenia się w działalność zespołów amatorskich. Mogą to być braki związane z fizyczną sprawnością, poziomem wykształcenia czy brakiem osoby bliskiej.

Metoda zuchowa. Ruch zuchowy, zaproponowany przez A. Kamińskiego, jest skierowany do dzieci w wieku 8-11 lat. Jego celem jest przygotowanie dzieci do funkcjonowania w zastępach harcerskich, ale nade wszystko wspomaganie procesu wychowania moralnego i patriotycznego dzieci oraz pobudzanie w nich chęć pracy nad sobą. Formacja ta, podobnie jak harcerstwo, opiera normy postępowania na swoistym kodeksie moralnym ("Prawo Zucha"):

- Zuch kocha Polskę.

- Zuch jest dzielny.

- Zuch mówi prawdę.

- Zuch pamięta o swoich obowiązkach.

- Wszystkim jest z zuchem dobrze.

- Zuch stara się być coraz lepszy [3, s. 20].

Praca wychowawcza z zuchami polega na sugerowaniu pojęć dobra i zła, jak również na takim oddziaływaniu na dzieci, by poprzez zabawę zinternalizowały zasady moralne zawarte w Prawie Zucha i wykształciły takiż sposób postępowania w swoim życiu.

Metoda wykorzystywana $\mathrm{w}$ pracy wychowawczej $\mathrm{z}$ zuchami opiera się na organizowaniu zbiórek harcerskich, w czasie których dzieci majsterkują, tańczą, śpiewają, biorą udział w zabawach. Zabawy, którym oddają się zuchy, wymagają posłuszeństwa, współdziałania, opanowania i poświęcenia, gdyż ich celem nie jest zabawa sama w sobie, lecz nabranie "dobrych przyzwyczajeń" [3, s. 20]. Zakończenie cyklu, który zdaniem A. Kamińskiego powinien obejmować 8-10 zbiórek, jest obrzęd próby sprawnościowej i nadanie sprawności.

Metoda organizowania działalności samorządnej. A. Kamiński przysłużył się teorii wychowania, $\mathrm{m}$. in. rozwijając spuściznę Janusza Korczaka w zakresie samorządności dzieci i młodzieży. Według A. Kamińskiego samorząd dzieci i młodzieży jest "instytucją, realizującą samorządność $w$ formie stowarzyszenia", zaś samorządność traktował jako metodę oddziaływań wychowawczych, której celem jest umożliwienie wychowankowi stanie się osobą samodzielną i odpowiedzialną, zdolną do autosterowania [4, s. 13].

A. Kamiński wyróżnił przejawy działalności samorządowej:

- organizowanie przez wychowanków różnych form spędzania wolnego czasu, związanego z odpoczynkiem, rozrywką i amatorskimi zajęciami kształcącymi w taki sposób, aby zaspokajały ich potrzeby;

- udzielanie samopomocy koleżeńskiej w zakresie materialnym i moralnym tym, którzy znaleźli się w trudnej sytuacji życiowej (chwilowej lub bardziej trwałej);

- ponoszenie współodpowiedzialności za ład i porządek w życiu szkoły lub placówki, ze szczególnym uwzględnieniem sprawowania dyżurów (zwłaszcza przez młodzież); 
- wspólne rozwiązywanie sporów koleżeńskich, także związanych z naruszaniem ogólnie obowiązujących norm współżycia.

Kamiński rekomendował powoływanie różnorakich sekcji i kół zainteresowań, takich jak koła naukowe, artystyczne, techniczne, jak również koła hodowlane, kolekcjonerskie czy też sportowe, krajoznawcze i turystyczne. Daje to dzieciom i młodzieży możliwość organizowania czasu wolnego w grupie osób o podobnych zainteresowaniach.

Metody adaptacji społecznej osób starszych. A. Kamiński wskazywał na potrzebę asymilacji osób starszych do zmieniających się warunków społecznych oraz nowej sytuacji życiowej osób na emeryturze. Zauważał, że wiele osób pełnych wigoru zmaga się z czasem całkowitej wolności i możliwości rozporządzania wolnym czasem, gdyż nie wiedzą, jak go spożytkować.

A. Kamiński popierał rodzące się na początku lat 70. postulaty, dotyczące umożliwienia seniorom stopniowego wycofywania się z rynku pracy, zależnie od stanu zdrowia i preferencji osób osiągających wiek emerytalny. Argumentował to ochroną starzejących się osób przed poczuciem bezużyteczności i dezorganizacji życia oraz nagłym obniżeniem się standardu życia. Podkreślał, iż tak drastyczna zmiana w życiu człowieka może powodować obawę przed utratą dotychczasowej pozycji społecznej i niezależności, a w konsekwencji frustrację i drażliwość [5, s. 360].

Wczasowanie analizował A. Kamiński jako obszar ułatwiający przeżywanie "jesieni życia" w dwojaki sposób: jako czynnik zastępczy pracy, aktywność amatorską, która może przynosić także korzyści materialne oraz jako formę spędzania wolnego czasu, odpoczynku, zaspokajanie zainteresowań kulturalnych, naukowych czy społecznych. A. Kamiński rekomendował, aby wczasowanie było połączone z ruchem lub aby dbałość 0 kondycję fizyczną była realizowana w postaci spacerów, uprawiania sportów czy gimnastyki.

Aleksander Kamiński określał proces zanikania kontaktów międzyludzkich w wieku emerytalnym jako "początek obumierania społecznego" [5, s. 363]. Podkreślał, że podtrzymywanie kontaktów koleżeńskich, rodzinnych i sąsiedzkich jest wskaźnikiem witalności. Proponował, aby odpowiednio wcześnie rozpocząć przygotowania do podtrzymywania i zawierania nowych znajomości w wieku senioralnym i rozwijania cech takich jak uczynność czy życzliwość oraz osłabianie cech takich jak arbitralność, narzucanie się, złośliwość.

Znaczenie spuścizny A. Kamińskiego we współczesnej praktyce pedagogicznej. Dorobek A. Kamińskiego ma nadal realne znaczenie dla wychowania, ze względu na to, iż spostrzeżenia i propozycje jakie prezentował, dotyczą ogółu społeczeństwa w różnych fazach rozwoju człowieka, dotykając fundamentalnych sfer jego rozwoju. A. Kamiński "widział" człowieka całościowo - jako istotę, której sfery funkcjonowania (biologiczna, społeczna, kulturowa) nie funkcjonują oddzielnie, lecz integralnie, zaś jednostka ludzka przechodzi przez różne fazy życia: od dzieciństwa po wiek senioralny oraz że należy o rozwój tego człowieka zatroszczyć się w równym stopniu w każdej z tych faz.

A. Kamiński zauważył, że aby intensywnie przeżywać wiek senioralny, konieczne jest wykształcenie odpowiednich zachowań i nawyków w toku życia. Jest to o tyle aktualne dziś, iż coraz więcej w społeczeństwie europejskim jest osób starszych, zaś dzieci i osoby młode coraz częściej bywają opuszczone emocjonalnie i wychowawczo w swoich środowiskach, czego przyczyną są minimalne kontakty między dziećmi a rodzicami. Skutkuje to chaosem w sferze wartości i problemami emocjonalnymi, prowadzącymi do utraty sensu życia oraz zaburzeń afektu. Kontakty interpersonalne, jakie dziś podejmuje młodzież z rówieśnikami, odbywają się coraz częściej za pomocą różnego rodzaju komunikatorów, zubażając tym samym pole do faktycznego "bycia ze sobą". Tym samym można spodziewać się ze strony młodych ludzi braku umiejętności odnalezienia się w życiu społecznym jako pracowników i obywateli.

Zaczynając od lat dziecięcych i młodzieńczych należy wdrażać człowieka do samodoskonalenia się oraz podejmowania przeróżnych aktywności pozaobowiązkowych, tj. nie związanych z obowiązkiem szkolnym czy pracą zawodową. Wśród takowych A. Kamiński wskazywał specjalizowanie się w różnych dziedzinach zawodowych (kształcąc się na różnorakich kursach, szkołach wyższych i innych ośrodkach kształcenia ustawicznego), podejmowanie prac amatorskich (rozwijanie swoich zdolności 
artystycznych, angażowanie się w działalność PTTK, prowadzenie przydomowgo ogródka), aktywność społeczną i polityczną, wewnątrzrodzinną aktywność opiekuńczą i usługową oraz pomoc sąsiedzką.

Przymioty, które umożliwiają tego typu aktywność kształtują przytaczane już ruch zuchowy i zespoły amatorskie. Pomagają dzieciom i młodzieży pokonywać lęk i stawać się "dzielnymi" ludźmi, odkrywać swoje nowe możliwości i umiejętności oraz w pewien sposób "dyscyplinują" swoich członków, aby nie rezygnowali z aktywności w chwilach słabości.

Szkoła również powinna wspierać rozwój młodych ludzi w tym zakresie, zatem zasadne jest stosowanie metody organizowania działalności samorządowej oraz metod aktywizujących proponowanych przez A. Kamińskiego (zabawy dydaktyczne, zajęcia w grupach, lista umiejętności). Przysposabia to młodych ludzi do podejmowania działania i wysitku.

Mając na względzie osoby dorosłe, należałoby wspierać je w samorozwoju w kręgu koleżeńskim zakładu pracy czy zespołów amatorskich. Jak podkreśla A. Kamiński te ostatnie stymulują osoby dorosłe, które podjęły już stałą pracę zawodową do dalszego kształcenia się: podnoszenia swoich kwalifikacji zawodowych bądź też zdobywania kwalifikacji, umożliwiających zmianę profesji.

Podsumowanie. A. Kamiński w czasie swojej działalności pedagogicznej nie stawiał wobec podmiotów oddziaływań barier w postaci wieku, wykształcenia czy dobrostanu psychospołecznego. Aktywność pedagogiczna A. Kamińskiego dotyczyła zarówno dzieci, młodzieży jak i osób dorosłych, w tym także seniorów. Podejmował tematykę uczniów zdolnych oraz "biernych i niezdolnych", a także młodzieży sprawiającej problemy wychowawcze, natomiast w uprawianej przez siebie pedagogice społecznej troską otaczał dobro rozwojowe osób zagrożonych wykluczeniem społecznym.

Wobec tak uniwersalnego podejścia do podmiotu oddziaływań wychowawczych A. Kamiński zajmował się szerokim repertuarem metod oddziaływań, adekwatnych do wieku i potrzeb rozwojowych podmiotów nimi obejmowanych. Opracował podstawy teoretyczne metody zuchowej oraz rozwinął korczakowską metodę działalności samorządowej. Kwintesencją koncepcji pedagogicznej Aleksandra Kamińskiego są, poparte praktyką pedagogiczną, teoretyczne rozważania nad aktywizacją i uspołecznieniem dzieci w placówce szkolnej. Wśród godnych uwagi zabiegów pedagogicznych, dedykowanych przez A. Kamińskiego osobom dorosłym, warto również zwrócić uwagę na zespoły amatorskie oraz metody adaptacji społecznej osób starszych.

Stosowanie metod proponowanych przez A. Kamińskiego ma we współczesnej pracy wychowawczej szerokie zastosowanie, dzięki uniwersalności tychże metod adekwatnie do wieku i poziomu wykształcenia wychowanków. Stosowane wobec dzieci i młodzieży owocują pożądanymi w późniejszych okresach życia postawami, zaś wdrażane u osób dorosłych podtrzymują te postawy.

\section{Bibliografia}

1. Janowski A. (1992). Być dzielnym i umieć się różnić - Szkice o Aleksandrze Kamińskim. Warszawa: Wydawnictwo Naukowe PWN.

2. Kamiński A. (1966). Aktywizacja i uspołecznienie uczniów w szkole podstawowej. Warszawa: PZWS.

3. Kamiński A. (1984). Książka drużynowego zuchów. Bytom: Śląsk.

4.Kamiński A. (1973). Samorząd młodzieży jako metoda wychowawcza. Warszawa: PZWS. PWN.

5. Kamiński A. (1978). Studia i szkice pedagogiczne. Warszawa: Wydawnictwo Naukowe

6. Latusk A. (2003). Słownik pisarzy polskich. Kraków: Zielona Sowa.

7. Łobocki M. (2009). Teoria wychowania. Kraków: Oficyna Wyd. Impuls.

8. Polańczyk D. (2006). "Kamienie na szaniec" Aleksandra Kamińskiego. Lublin: Biblios.

9. Sułka H. (2003). Słownik lektur. Kraków: Zielona Sowa.

\section{References}

1. Janowski, A. (1992). Być dzielnym i umieć się różnić - Szkice o Aleksandrze Kamińskim [Be brave and be able to differ - Sketches about Aleksander Kamiński]. Warszawa: Wydawnictwo Naukowe PWN [in Polish]. 
2. Kamiński, A. (1966). Aktywizacja i uspołecznienie uczniów w szkole podstawowej [Activation and socialization of students in primary school]. Warszawa: PZWS [in Polish]. Śląsk.

3. Kamiński, A. (1984). Książka drużynowego zuchów [Book of friendly zuchów]. Bytom:

4. Kamiński, A. (1973). Samorząd młodzieży jako metoda wychowawcza [Youth selfgovernment as an educational method]. Warszawa: PZWS [in Polish].

5. Kamiński, A. (1978). Studia i szkice pedagogiczne [Pedagogical studies and sketches]. Warszawa: Wydawnictwo Naukowe PWN [in Polish].

6. Latusk, A. (2003). Słownik pisarzy polskich [Dictionary of Polish writers]. Kraków: Zielona Sowa [in Polish].

7. Łobocki, M. (2009). Teoria wychowania [The theory of education]. Kraków: Oficyna Wyd. Impuls [in Polish].

8. Polańczyk, D. (2006). "Kamienie na szaniec" Aleksandra Kamińskiego ["Stones for the Rampart" by Aleksander Kaminski]. Lublin: Biblios [in Polish]. Polish].

9. Sułka, H. (2003). Słownik lektur [Dictionary of reading]. Kraków: Zielona Sowa [in

\section{Лісовець 0.}

доктор педагогічних наук, професор кафедри соціальної педагогіки та соціальної роботи Ніжинського державного університету імені Миколи Гоголя, Україна

\section{Мачох М.}

студентка магістратури "Педагогічна допомога та освітня соціальна профілактика", Державна школа вищої освіти м. Хелм, Польща

\section{ВНЕСОК ОЛЕКСАНДРА КАМІНСЬКОГО В РОЗВИТОК ТЕОРІЇ ОСВІТИ}

У статті представлено аналіз внеску у розвиток теорії виховання видатного польського педагога, скаутського інструктора О. Камінського. Розглянуто життєвий та педагогічний шлях педагога, його місце у формуванні польського скаутського руху. Представлено педагогічну концепцію О. Камінського. Проаналізовано методи виховання на основі активізації, групової взаємодії та організації самоврядування. Показана роль дидактичних ігор у виховному процесі. Проаналізовано значення спадщини О. Камінського в сучасній педагогічній практиці.

Ключові слова: виховання, теорія виховання, груповий метод, самоврядування дітей та молоді, скаутський рух.

\section{Lisovets 0 .}

doktor of Pedagogical Sciences, Professor Department of Social Pedagogy and Social Work, Nizhyn Mykola Gogol State University, Ukraine

\section{Macioch M.}

Master's student Pedagogy care and educational social prevention, The State School of Higher Education in Chelm, Poland

\section{ALEKSANDER KAMINSKI'S CONTRIBUTION TO THE DEVELOPMENT OF THE THEORY OF EDUCATION}

The contribution of an outstanding teacher, scout instructor A. Kaminsky in the development of the theory of education is considered in the article. Today, the Polish scouting movement uses the basic structures, methodological assumptions, pedagogical ideas and organizational solutions proposed by A. Kaminsky. The life and pedagogical way of a teacher, his place in the formation of the Polish scouting movement are considered. The pedagogical concept of $A$. Kaminsky is presented. Methods of education based on activation, group interaction and organization of self-government activities are analyzed. The role of didactic games in the educational process is shown. A. Kaminsky's views on 
children's and youth self-government are presented. The teacher considered this selfgovernment as a method of educational interactions, the purpose of which is to enable the child to become an independent and responsible person capable of self-control. The realization of these ideas is reflected in the conditions of the Polish scouting movement, to the formation of which A. Kaminsky was directly related. The teacher adapted the scout method, emphasized the role of public organization in the process of self-education and socialization of children, youth and adults. Another direction of A. Kaminsky's pedagogical concept is highlighted - work with elderly people. The teacher proposed methods of social adaptation of the elderly, which are aimed at overcoming the social maladaptation and social isolation of this group. The significance of $A$. Kaminsky 's legacy in modern pedagogical practice is analyzed. It is concluded that the methods proposed by A. Kaminsky are widely used in modern educational work due to the universality of these methods, their age adequacy and level of education.

Key words: education, theory of education, group method, self-government of children and adolescents, Polish scouting movement 